\title{
Imersifitas Game untuk Pembelajaran Sejarah
}

\author{
Abi Senoprabowo, Noor Hasyim \\ Jurusan Desain Komunikasi Visual, UDINUS Semarang
}

\begin{abstract}
Abstrak. Pendidikan sejarah saat ini sangat kering dan membosankan. Siswa didik hanya belajar melalui buku dengan cara menghafalkan nama dan kapan peristiwa tersebut terjadi. Hal ini membuat generasi muda jenuh belajar sejarah. Belajar sambil bermain menjadi terobosan dalam sistem belajar. Dalam mendidik siswa, dapat digunakan sistem pembelajaran berbasis pengalaman. Game adalah salah satu media interaktif yang menjadi solusi belajar sambil bermain. Salah satu faktor penting dalam game bersifat imersif, dapat membuat pemain seakanakan larut didalam game dan tidak peduli dengan keadaan di sekitarnya. Sifat imersif juga dapat mempengaruhi penerimaan pemain terhadap isi dan pesan dari game. Imersifitas membuat pemain dapat seolah-olah menjadi bagian dalam peristiwa dalam game. Game memberikan pengalaman pada pemain game, sehingga dapat dimanfaatkan untuk pembelajaran sejarah. Tulisan ini akan membahas pemanfaatan imersifitas game dalam pembelajaran sejarah melalui studi kasus pada Game Samurai Warriors.
\end{abstract}

Kata Kunci: Imersifitas, Game, Pendidikan Sejarah

\section{PENDAHULUAN}

Selama KBM (kegiatan belajar mengajar) guru belum memberdayakan seluruh potensi dirinya sehingga sebagian besar siswa belum mampu mencapai kompetensi individual yang diperlukan untuk mengikuti pelajaran lanjutan. Beberapa siswa belum belajar sampai pada tingkat pemahaman. Siswa juga masih menganggap sejarah sebagai pelajaran hafalan dan membosankan. Pembelajaran ini dianggap tidak lebih dari rangkaian angka tahun dan urutan peristiwa yang harus diingat kemudian diungkap kembali saat menjawab soal-soal ujian. Kenyataan ini tidak dapat dipungkiri, karena masih terjadi sampai sekarang. Pembelajaran sejarah yang selama ini terjadi di sekolah-sekolah dirasakan kering dan membosankan. Karakteristik pelajaran sejarah menurut Balai Pelestarian Sejarah dan Nilai Tradisional Bandung (2008) adalah

1. Sifat Peristiwa, peristiwa yang dicatat dalam pelajaran sejarah menyangkut individu, institusi, situasi, dan juga ide.

2. Perspektif Waktu, sejarah mengacu pada periodisasi (pembabakan waktu)

3. Sifat Fakta, sejarah harus berdasarkan fakta. 
Sedang proses pembelajaran sejarah yang baik adalah sistem pembelajaran yang menggunakan empat kegiatan belajar yaitu kegiatan pencarian informasi, kegiatan pemahaman informasi, kegiatan penggunaan informasi, dan kegiatan pemanfaatan informasi (Hamid, 2010). Dalam kegiatan pencarian informasi, peserta didik yang belajar sejarah harus dapat mengidentifikasi berbagai jenis informasi yang diperoleh dari suatu sumber, seperti: fakta, konsep, generalisasi, teori, prosedur, proses, nilai, dan sebagainya. Setelah melakukan kegiatan mencari informasi, informasi tersebut harus dipahami oleh siswa dalam kegiatan pemahaman. Pada kegiatan penggunaan informasi, peserta didik harus menerapkan hasil pemahaman kedalam kehidupan bermasyarakat. Kegiatan pemanfaatan merupakan kegiatan yang terpenting, yaitu menerapkan pemahaman tersebut untuk menemukan jati diri peserta didik, tentu saja melalui bimbingan guru. Untuk melakukan kegiatan penggunaan dan pemanfaatan sejarah, siswa didik dipastikan harus melakukan kegiatan pencarian dan pemahaman informasi. Kegiatan pencarian dan pemahaman informasi yang kurang menarik dapat menghambat proses kegiatan penggunaan dan pemanfaatan sejarah, bahkan dalam pemahaman sejarahpun akan terhambat. Keterlibatan (imersifitas) peserta didik dalam melakukan pencarian informasi menjadi sangat penting. Dengan terlibatnya mereka mencari informasi dapat membuat peserta didik tertarik dan pada akhirnya memperlancar proses kegiatan selanjutnya.

\section{METODE DAN PEMBAHASAN}

\section{Belajar Sejarah Melalui Game}

Pembelajaran sejarah dapat melalui game karena pembelajaran sejarah yang baik adalah sistem pembelajaran yang menggunakan empat kegiatan belajar seperti telah dituliskan sebelumnya, yaitu kegiatan pencarian informasi, kegiatan pemahaman informasi, kegiatan penggunaan informasi, dan kegiatan pemanfaatan informasi. Keempat kegiatan tersebut dapat dilakukan melalui game. Kegiatan belajar sambil bermain juga dapat meningkatkan keinginan peserta didik dalam memahami suatu hal. Seperti yang dicontohkan Negroponte (1998, 198-200) ketika anak dihadapkan pada sebuah permainan Lego. Lego adalah sebuah 
permainan menyusun balok-balok untuk membuat suatu bentuk yang lain seperti rumah, mobil, pesawat, dan lain sebagainya. Ketika anak diberikan tugas untuk menyusun suatu bentuk, anak akan mencoba memainkan Lego tersebut sesuai dengan keinginan dan perspektif mereka. Anak akan sangat senang dengan setiap penemuan dan dari situ ia akan bisa menyerap pengetahuan secara langsung. Waktu bermain adalah satu area yang paling memberikan rasa senang, relaksasi, hiburan dan merupakan sosialisasi pendidikan untuk semua orang. Selama bermain, pihak lain juga bisa membantu anak membayangkan dunia baru secara keseluruhan. Ketika bentuk tersebut sudah selesai, diberikan apresiasi terhadap mereka. Mereka akan merasa menjadi pahlawan karena telah menyelesaikan bentuk tersebut. Kemudian ditanya tentang bagaimana mereka menyelesaikan bentuk tersebut dan bagaimana bentuk tersebut bekerja. Momen kemenangan seperti inilah yang memberikan mereka sesuatu yang penting, yaitu kesenangan dalam belajar.

Negroponte (1998, 203-204) mengajarkan sesuatu berbasis pada pengalaman. Pengalaman belajar memecahkan teka-teki melalui kegiatan berburu angsa, membuat dia selalu ingat akan pelajaran yang didapat tersebut. Kegiatan berburu angsa tersebut mengharuskan Negroponte terjun langsung ke lapangan. Untuk menemukan tempat berburu angsa serta mengetahui bagaiman mendapatkan angsa, dia harus menyelesaikan sebuah teka-teki. Dengan kegiatan yang dilakukan sendiri, membuat dia mendapatkan sebuah pengalaman baru. Hal ini berbading terbalik dengan anak-anak dewasa ini, mereka belajar hanya dengan membaca buku. Negroponte memukan perbedaan nyata antara pintar lewat pengalaman dan pintar lewat buku. Pintar melalui pengalaman akan tersimpan lebih lama di otak dibandingkan pintar melalui buku. Pengalaman yang menawarkan kesenangan dan gerak motorik akan lebih disimpan dibandingkan dengan kegiatan yang membosankan seperti membaca buku.

Pendekatan pembelajaran sejarah dapat menggunakan pendekatan belajar melalui pengalaman. Belajar melalui pengalaman sekarang sudah bisa dilakukan melalui media interaktif, seperti internet dan game. Anak bisa menjelajah kemanapun 
yang mereka inginkan sehingga mendapatkan pengalaman dalam belajar. Siswa didik dapat dibuatkan sebuah simulasi pembelajaran sejarah melalui media game. Game adalah struktur interaktif yang membuat pemain berjuang menuju sebuah tujuan. Game memiliki unsur penting yang harus ada, yaitu fun (kesenangan). Unsur fun ini yang membuat anak-anak senang memainkan game. Peristiwaperistiwa sejarah yang monoton dalam buku dibuat simulasi kejadiannya melalui game. Dalam game tersebut siswa didik dapat diberikan peran sebagai salah satu pelaku dalam peristiwa tersebut. Dengan seolah-olah menjadi pelaku dalam peristiwa tersebut, siswa didik akan mengerti apa yang tejadi pada peristiwa tersebut sehingga siswa didik mendapat pengalaman baru dalam belajar. Siswa didik dapat memilih peran yang lain dalam peristiwa tersebut. Pemilihan peran tersebut membuat peserta didik tidak hanya mengetahui peristiwa dari satu prespektif, tetapi dari perspektif yang lain juga. Hal ini akan menumbuhkan pemahaman-pemahaman baru tentang peristiwa tersebut.

Game dapat berguna untuk kegiatan yang berhubungan dengan edukasi (Schell, 2008). Berikut adalah keuntungan game untuk edukasi:

1. Fakta, beberapa game dibuat untuk menyampaikan fakta dan berusaha menggali fakta yang ada. Fakta-fakta tersebut seperti tentang sejarah, tata surya, geografi, penyakit menular, dan sebagainya. Game juga dapat memanfaatkan objek visual untuk membantu pemain belajar fakta-fakta.

2. Pemecahan masalah, dalam definisi game sendiri, game memang sebuah permainan memecahkan masalah untuk mencapai tujuan, sehingga pada dasarnya bermain game selalu memecahkan masalah. Namun untuk game simulasi dapat digunakan lebih maksimal, seperti kerja polisi dan penyelamatan, geologi, arsitektur, manajemen, dan lain-lain.

3. Wawasan baru, banyak pengetahuan baru yang didapat oleh pemain ketika bermain game, ini dikhususkan untuk game yang mengangkat fakta-fakta.

4. Keingintahuan, pemain akan merasa penasaran untuk mendapatkan nilai yang lebih dari teman mereka. Rasa penasaran tersebut dapat membuat pemain untuk belajar hal-hal sendiri dan mereka belajar karena mereka mau. Dalam arti, rasa ingin tahu membuat pemain berusaha belajar. Pemain yang 
penasaran akan belajar atau memainkan game tersebut sebanyak yang dia inginkan untuk memuaskan keinginan mereka. Sehingga dapat dikatakan bahwa keingintahuan merupakan aset yang sangat berharga dalam proses edukasi.

Dari hal-hal diatas dapat diketahui bagaimana pemain belajar bagaimana proses pemain mendapat pengetahuan baru seperti dalam piramida Miller berikut,

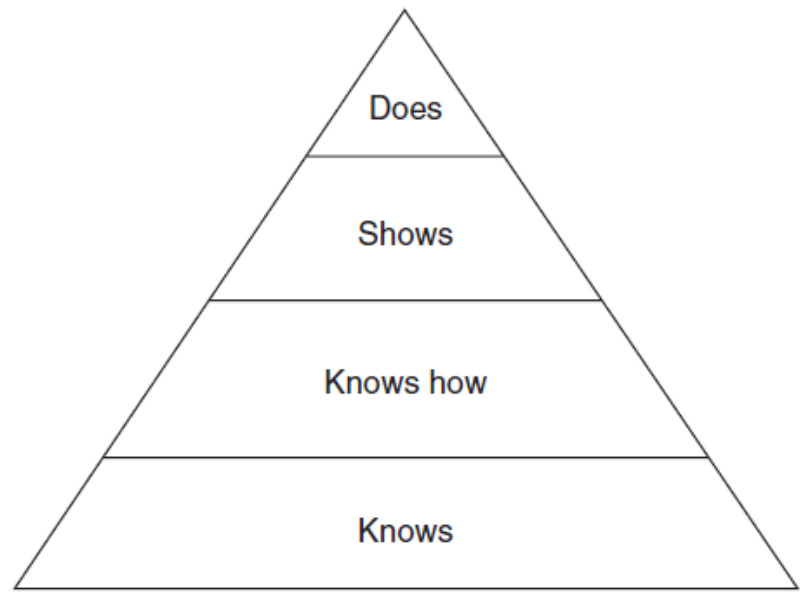

Gambar 2.3 Piramida proses belajar pada game menurut Schell

Dari piramida tersebut dapat dibaca proses pemahaman pemain dalam sebuah fakta. Pada tahap awal, pemain hanya diajak untuk mengerti (knows) tentang sebuah fakta. Setelah itu pada tahap berikutnya dengan sendiri atau secara tidak langsung pemain akan mengetahui bagaimana fakta tersebut bisa terjadi (knows how). Pada tahap selanjutnya pemain akan mencari atau menunjukan fakta yang lebih detail (shows). Setelah itu mereka akan bisa menjadi ahli atau tahu secara pasti fakta tersebut (does).

Pendekatan game dalam mengajarkan sejarah yakni dengan cara eksplorasi dan pengumpulan kembali pengalaman serta menemukan pelajaran untuk diri mereka sendiri. Mereka dapat memahami bahwa yang dilakukan pada game tersebut merupakan visualisasi dari suatu peristiwa sejarah. Karena keunggulannya, game dapat memberikan simulasi yang baik pada suatu peristiwa tertentu. Dengan keunggulan ini, game dapat mengungkapkan karasteristik pelajaran sejarah yang 
mengandung tentang sifat peristiwa, (nama individu, institusi, situasi, dan ide), perspektif waktu (periodisasi / pembabakan waktu), dan sifat fakta (sejarah harus berdasarkan fakta).

Memasukkan game sebagai media belajar memang masih susah untuk masyarakat Indonesia sekarang. Kebanyakan para orang tua gagal memahami bagaimana anak-anak belajar game (Negroponte, 1998). Para orang tua hanya berasumsi bahwa game itu sangat menarik sehingga anak-anak mudah kecanduan. Hal ini juga menjadi mitos yang masih berkembang dalam masyarakat Indonesia. Para orang tua jarang yang berfikir bahwa game bisa mengajarkan anak-anak bermain strategi dan melatih kemampuan perencanaan akan suatu hal. Kemampuan mengatur strategi dan perencanaan kelak akan anak-anak butuhkan ketika mereka sudah menjadi dewasa. Game juga dapat memberikan pelajaran tentang kecepatan respon anak, seperti pada game puzzle. Dewasa ini game juga menawarkan banyak informasi seperti sejarah, fisika, kimia, biologi, geologi, dan sebagainya.

\section{Imersifitas Game}

Seperti pembahasan sebelumnya, game adalah media yang tepat untuk sarana pembelajaran berbasis pada pengalaman. Pengalaman dapat terbentuk dengan memanfaatkan sifat imersif game. Imersifitas adalah perasaan untuk berpartisipasi dan perasaan "being there" pada sebuah game (Newman, 2004). Imersifitas dalam game dapat membuat pengguna menjadi merasa benar-benar terbawa kondisi tertentu. Imersifitas mempengaruhi peran serta pengguna dalam memainkan game. Imersifitas juga membuat pemain menyatu dengan game. Pengguna akan merasa game yang mereka mainkan adalah sebuah realitas baru, sehingga pelajaran sejarah akan mudah mereka tangkap. Ada beberapa ciri keadaan dimana orang menjadi imersif terhadap game Menurut (Sweetser \& Wyeth, 2005). Ciri tersebut dapat terlihat ketika pemain merasakan hal seperti:

1. Pemain menjadi kurang menyadari keadaan di sekitarnya.

2. Pemain menjadi kurang menyadari keadaan dirinya sendiri dan kurang memperhatikan kebutuhan sehari-harinya. 
3. Pemain mengalami perasaan akan waktu yang berubah (waktu di dalam Game dengan waktu sebenarnya).

4. Pemain merasa terlibat secara emosi dalam Game.

5. Pemain merasa terlibat didalam Game secara mendalam.

Ketika pemain merasakan hal diatas, mereka akan benar-benar menjadi bagian dari game tersebut.

Beberapa elemen yang mendukung imersifitas pemain pada sebuah game menurut Slater (2002) adalah:

1. Awal Game, awal Game sangat menentukan elemen imersif yang penting. Di awal Game, plot cerita sudah kelihatan, pengenalan karakter Game, dan apakah Game cukup mudah untuk dimainkan dalam menit-menit pertama. Pemain tidak suka Game yang terlalu rumit untuk dimainkan.

2. Video, video dapat membantu membangun sebuah realitas yang lebih nyata dan membuat pemain lebih imersif, tetapi jangan terlalu banyak.

3. Memberi imajinasi melalui cerita, setting cerita yang menarik membuat pemain mengikuti cerita dalam Game dan merasa terlibat secara emosi dengan karakter dalam Game.

4. Suara, suara / musik membantu pemain menciptakan suasana dan emosi. Suara yang sesuai dengan keadaan yang terjadi di Game menambah tingkat imersif Game.

5. Grafik, pembuatan Grafik karakter dan lingkungan Game yang menarik dan lebih nyata sangat berpengaruh pada tingkat imersif Game.

6. Kecerdasan buatan, kecerdasan buatan diantaranya mengatur perilaku dari Non-Playable Character (NPC) dan musuh. NPC yang berperilaku natural dan musuh yang menantang adalah faktor pembentuk pengalaman imersif yang penting.

7. GUI (graphical user interface), GUI yang rumit akan membuat pemain bingung dan merusak pengalaman imersif pemain. Sebaliknya, GUI yang bagus akan menambah pengalaman imersif pemain.

8. Desain level, desain level menentukan faktor kesenangan dari pemain. Desain level yang baik akan menambah pengalaman imersif pemain. 


\section{Game Samurai Warriors sebagai game berbasis sejarah}

Game yang baik dalam memberikan pemebelajaran sejarah salah satunya adalah Samurai Warriors. Game ini dibuat oleh Koei (sebuah developer Game dari Jepang), serta didistribusikan oleh EA (Electronic Arts). Game ini dirilis pada tahun 2004. Game ini berbasis pada sejarah bangsa Jepang. Setting Game ini berada pada zaman Sengoku. Sengoku adalah periode perang negara dalam sejarah Jepang yang berisi pergolakan sosial, intrik politik, dan konflik militer yang berlangsung kira-kira dari pertengahan abad ke-15 sampai awal abad ke-17. Dalam masa ini terjadi peperangan antara 3 kerajaan yang dipimpin oleh Oda Nobunaga, Toyotomi Hideyoshi, dan Tokugawa Ieyasu.

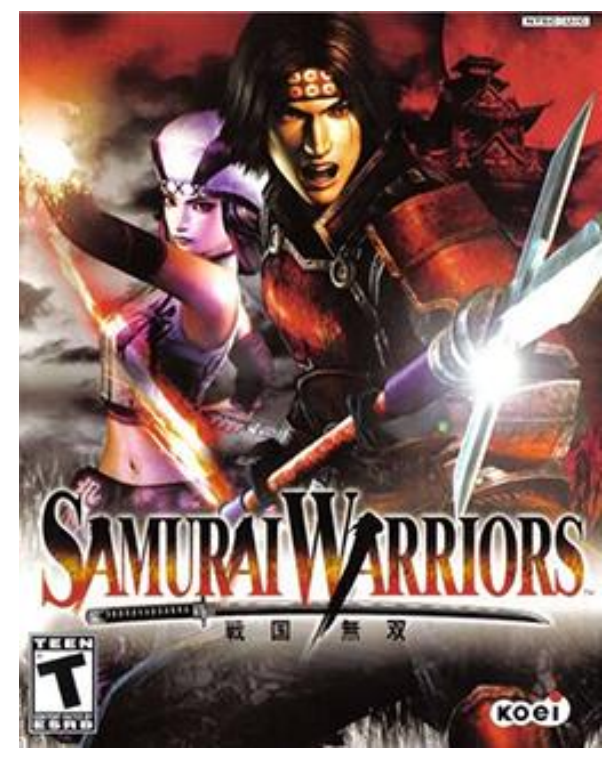

Cover CD Game Samurai Warriors Sumber : http://www.pwned.com/gamecovers/playstation2/20047c01f8c16be6ed58267d8757c8cf79d-Samurai_Warriors.png

Game yang di Jepang bernama Sengoku Musou ini pada saat rilis pertama kali di Jepang, terjual lebih dari 1 satu juta copy dalam waktu satu bulan dan memenangkan CESA Game Awards yaitu sebuah penghargaan Game yang dibuat oleh Tokyo Game Show yang merupakan penghargaan game yang bergengsi di Jepang. Dengan terjual lebih dari satu juta copy, secara tidak langsung game ini telah mempengaruhi generasi muda Jepang untuk memainkannya. Game ini secara tidak langsung telah membuat generasi muda Jepang mengetahui sejarah 
negara mereka sendiri. Bahkan di UCLA International Institute, Samurai Warriors digunakan sebagai bahan kajian tugas anak didik mereka untuk memahai sejarah dan budaya Jepang.

Dalam game ini terdapat berbagai karakter sejarah pada zaman Sengoku seperti: Nobunaga Oda, Yukimura Sanada, Keiji Maeda, Mitsuhide Akechi, Goemon Ishikawa, Kenshin Uesugi, Oichi, Okuni, Kunoichi, Magoichi Saika, Shingen Takeda, Masamune Date, Noh, Hanzo Hattori, dan Ranmaru Mori. Setiap karakter dalam game tersebut memiliki cerita sendiri-sendiri sesuai fakta sejarah yang ada. Ketika pemain memilih karakter yang mereka ingin mainkan, maka pemain akan berperan sebagai karakter tersebut. Sebagai contoh, berikut adalah elemen-elemen game Samurai Warriors ketika memilih karakter Nobunaga Oda,

\begin{tabular}{|l|l|l|l|}
\hline \multicolumn{2}{|c|}{ Game Samurai Warriors karakter Nobunaga Oda } \\
\hline No & Elemen & $\begin{array}{l}\text { Karakter } \\
\text { Nobunaga } \\
\text { Oda }\end{array}$ \\
\hline 1 & & \\
\hline
\end{tabular}




\begin{tabular}{|c|c|c|}
\hline 2 & Misi & $\begin{array}{l}\text { 1. Pertempuran Okehazama } \\
\text { - Menyerang pos Imagawa } \\
\text { - Menghilangkan musuh dekat Benteng Zenshouji } \\
\text { - Menyerang kamp utama Imagawa dari celah gunung } \\
\text { - Mengalahkan Hanzo Hattori } \\
\text { - Mengalahkan Tadakatsu Honda } \\
\text { - Mengalahkan semua pengawal Imagawa } \\
\text { - Mengalahkan perwira elit angkatan darat Imagawa } \\
\text { - Jangan biarkan Hanzo Hattori mengalahkanmu } \\
\text { - Mempertahankan kamp utama Oda } \\
\text { 2. Pertempuran Ise } \\
\text { - Menghilangkan pasukan pertahanan benteng } \\
\text { - Lindungi Unit meriam sampai serangan meriam dimulai } \\
\text { - Melindungi \& mengamankan jalan bagi gugus tugas } \\
\text { - Menempati keempat benteng musuh } \\
\text { - Kalahkan komandan musuh } \\
\text { - Melenyapkan Tentara Ikko } \\
\text { 3. Pertempuran Nagashino } \\
\text { - Pertahankan Gunung Chausu } \\
\text { - Menempati kubu musuh } \\
\text { - Mengalahkan 20 tentara Naito } \\
\text { - Jangan biarkan kavaleri Takeda jauh } \\
\text { - Kalahkan Yukimura Sanada } \\
\text { - Kalahkan Katsuyori Takeda } \\
\text { - Melenyapkan Kavaleri Takeda } \\
\text { 6. Pertempuran Nagashino } \\
\text { - Membantu Tokugawa menduduki benteng musuh } \\
\text { - Bergabung dan membantu Mitsuhide Akechi } \\
\text { - Kalahkan Masatoyo Naito atau Masakage Yamagata } \\
\text { - Membantu unit serangan api Oda } \\
\text { - Kalahkan semua musuh dalam gerbang } \\
\text { - Kalahkan Magoichi Saika } \\
\text { - Membantu unit serangan api Oda } \\
\text { - Kalahkan Noh } \\
\text { - Membantu unit serangan api Oda } \\
\text { - Membantu Oichi dan kalahan Keiji Maeda } \\
\text { - Kerebut kembali dari Istana Azuchi (dalam) } \\
\text { - Mencari dan menghilangkan Hanzo Hattori } \\
\text { - Kalahkan Magoichi Saika } \\
\text { - Kalahkan Noh }\end{array}$ \\
\hline
\end{tabular}




\begin{tabular}{|c|c|c|}
\hline & & $\begin{array}{l}\text { - Kalahkan Shingen Takeda } \\
\text { - Jangan biarkan kavaleri Takeda ke kamp utama } \\
\text { - Lindungi unit senapan sampai bisa menembak } \\
\text { 7. Mempertahankan istana Gifu } \\
\text { - Hancurkan Pengepung dan melindungi gerbang barat } \\
\text { - Ambil Kastil Sunomata dan gerbang utama } \\
\text { - Jangan biarkan Kenshin Uesugi dekat Keiji Maeda } \\
\text { - Kalahkan Keiji Maeda } \\
\text { - Kalahkan Ranpa } \\
\text { - Jangan biarkan mata-mata melarikan diri } \\
\text { - Mengambil alih kamp utama Uesugi } \\
\text { - Jangan biarkan Tentara Uesugi masuk istana Gifu } \\
\text { 8. Pertempuran Yamasaki } \\
\text { - Mengalahkan perwira musuh di gunung Ten-oh } \\
\text { - Pergi dan membantu Hideyoshi Hashiba } \\
\text { - Kalahkan Magoichi Saika } \\
\text { - Kalahkan Yukimura Sanada } \\
\text { - Mencegah Kunoichi dan Yukimura bergabung } \\
\text { - Mengawal Ranmaru Mori ke Mitsuhide Akechi } \\
\text { - Gunakan kabut untuk menyergap Mitsuhide Akechi }\end{array}$ \\
\hline 3 & $\begin{array}{l}\text { Scene } \\
\text { dalam } \\
\text { game }\end{array}$ & 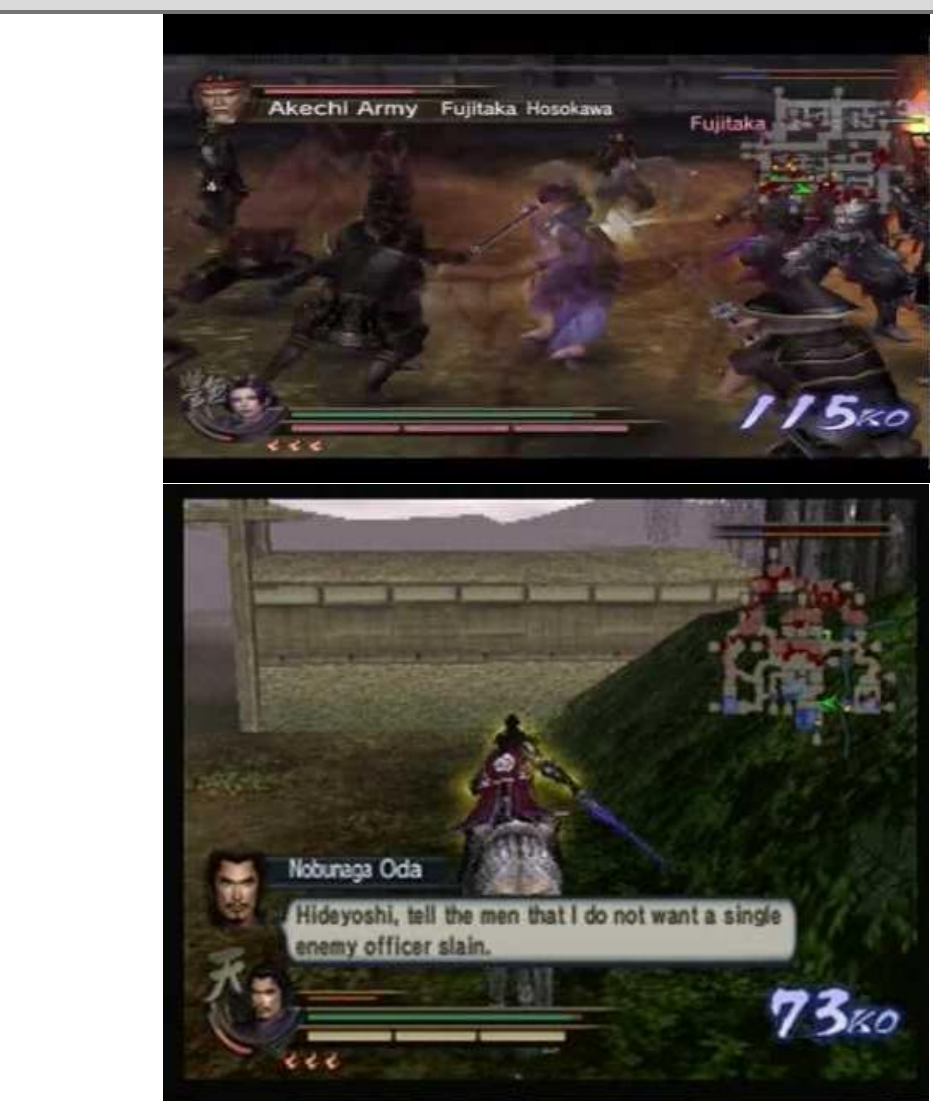 \\
\hline
\end{tabular}




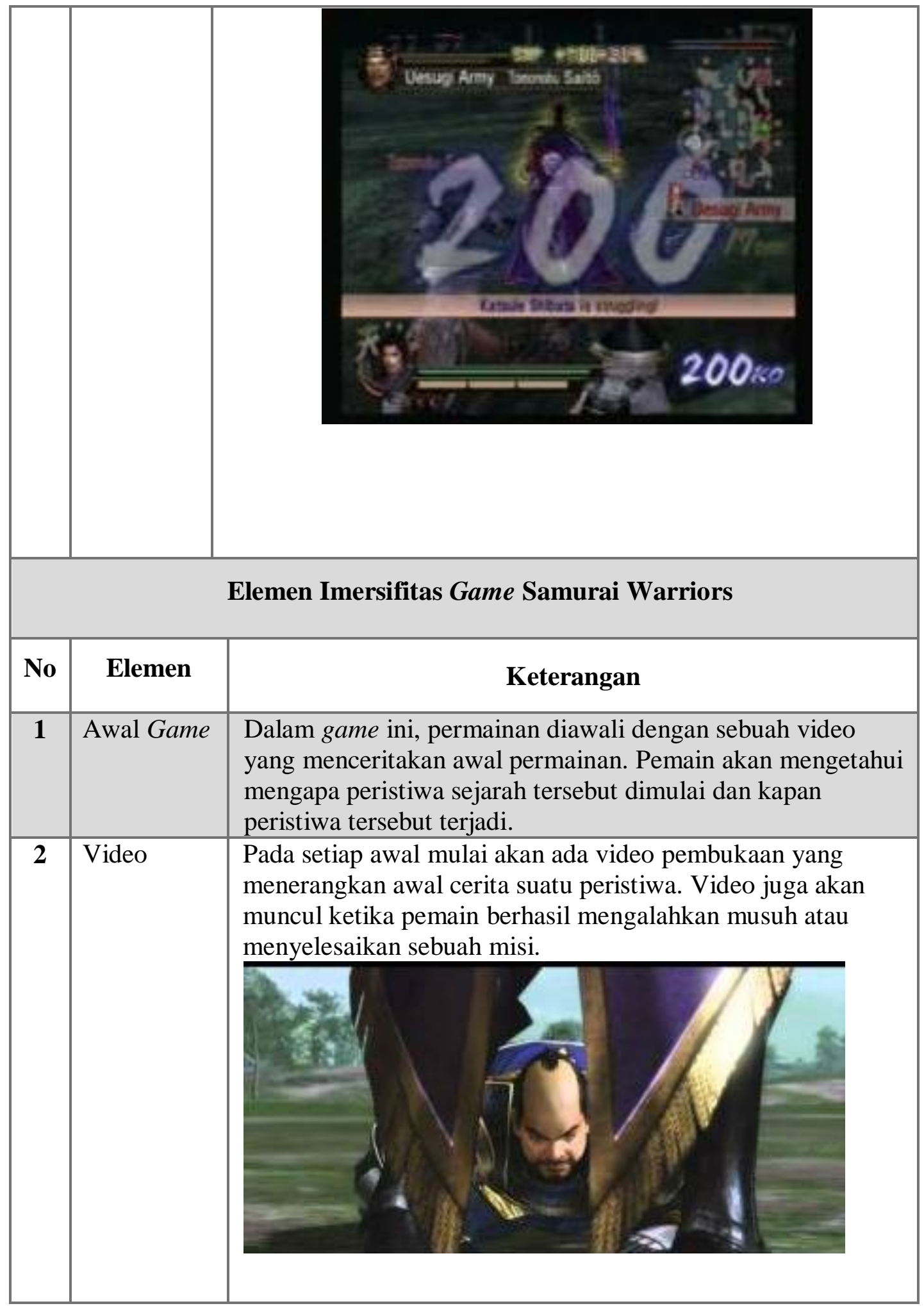

Program Studi Desain Komunikasi Visual, Universitas Komputer Indonesia 


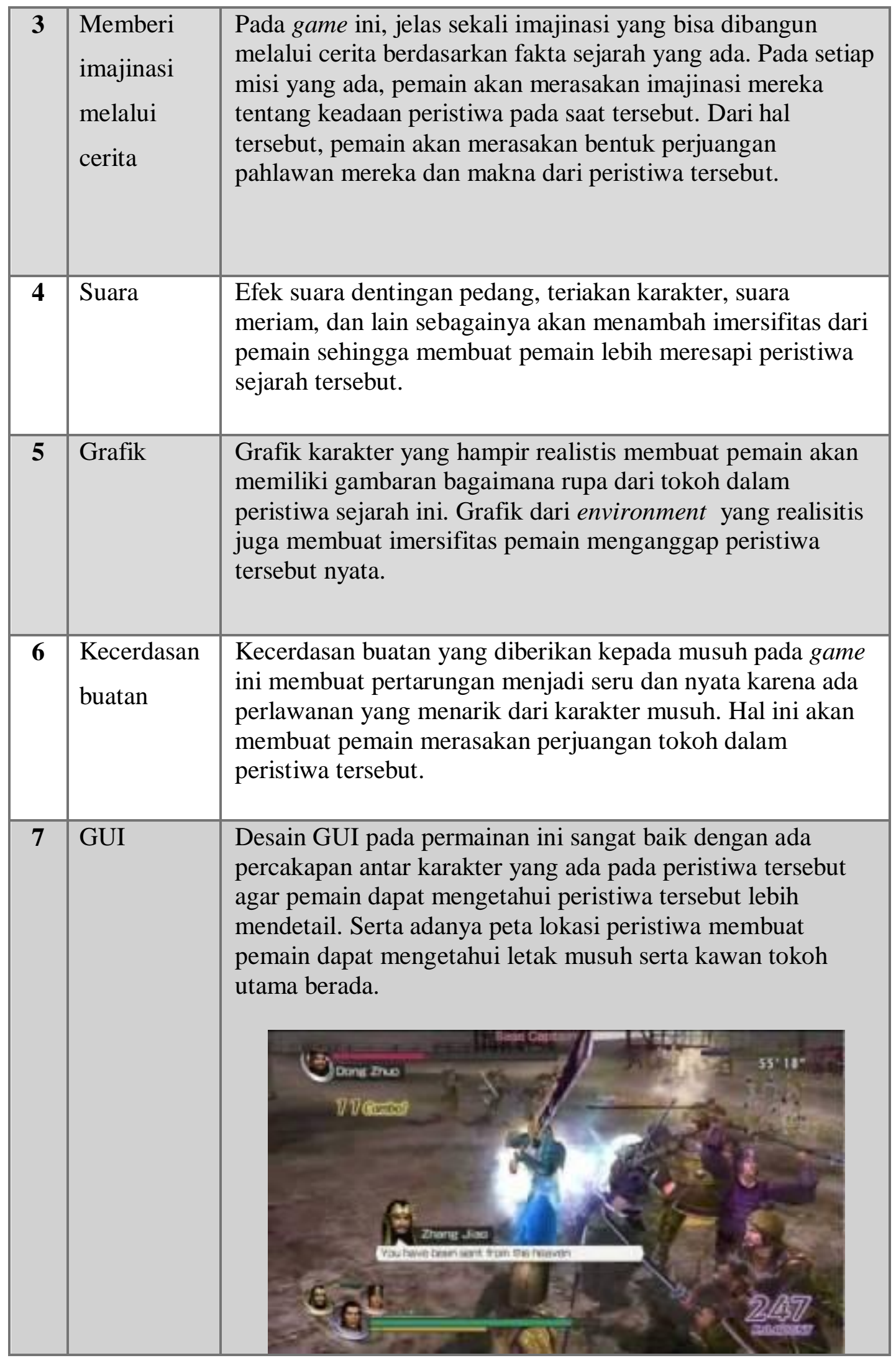

Program Studi Desain Komunikasi Visual, Universitas Komputer Indonesia 


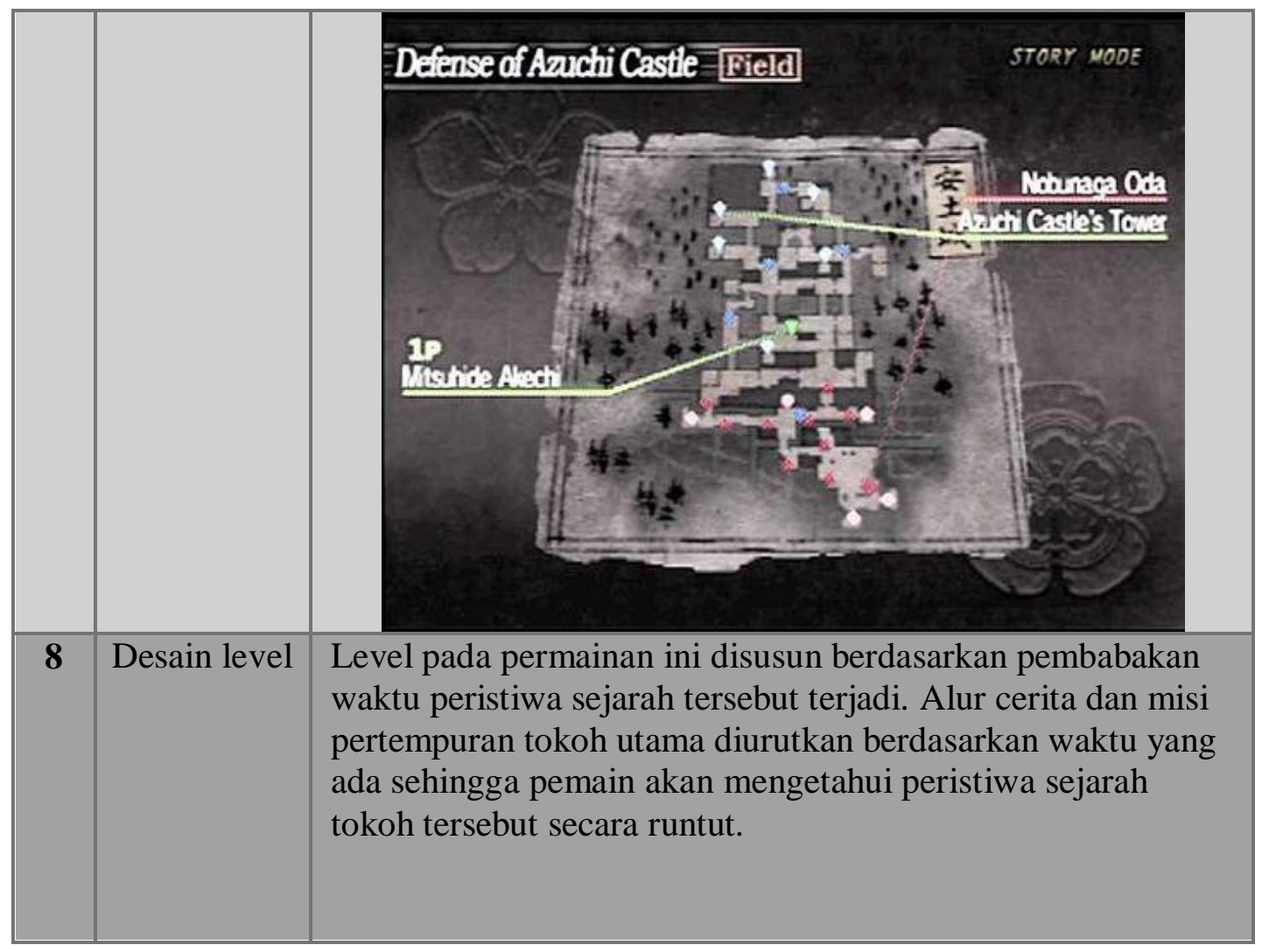

Dari game inilah dapat diambil kesimpulan bahwa sinergi antara pembelajaran sejarah dengan game dapat membantu anak-anak lebih mudah dalam memahami sejarah, tetapi dapat sukses dalam penjualan. Game Samurai Warriors memberi sudut pandang lain dalam menyikapi belajar sejarah yang menyenangkan. Dalam game ini pemain diberi pilihan peran sebagai salah satu tokoh dalam game tersebut. Pemberian peran ini membuat pemain lebih mudah memahami situasi dan jalan cerita yang terjadi dari masing-masing tokoh, sehingga pembelajaran sejarah menjadi menarik dan menyenangkan. Game ini juga berisi tentang semua karakteristik pembelajaran sejarah yaitu pencatatan peristiwa (nama individu, institusi, situasi), perspektif waktu (periodisasi/pembabakan waktu), dan Sifat Fakta (sejarah harus berdasarkan fakta).

\section{KESIMPULAN}

Pemanfaatan imersifitas pemain pada sebuah game dalam pembelajaran sejarah sangat dimungkinkan. Kerlibatan yang dalam pada sebuah game sejarah membuat siswa didik menjadi mudah memahami sejarah. Dengan menggunakan pendidikan 
berbasis game kita dapat memberikan stimulus pada tiga bagian penting dalam pembelajaran yaitu emosi, kecerdasan, dan psikomotorik. Pendidikan berbasis game adalah salah satu metode pembelajaran yang tepat dengan kondisi dari generasi digital sekarang ini karena tiga alasan berikut ini:

1. Menciptakan lingkungan belajar yang menyenangkan dan menambah motivasi siswa untuk belajar.

2. Kompetisi dan kerjasama tim dalam menyelesaikan misi yang ada dalam aplikasi game juga dapat menambahkan komponen motivasi pada siswa.

3. Umpan balik yang cepat dan spesifik memberikan kemudahan bagi siswa untuk memikirkan cara lain yang tepat untuk menyelesaikan penugasannya.

Secara garis besar pendidikan berbasis game adalah salah satu metode yang bisa digunakan dalam pembelajaran dan tentunya ini harus dilakukan secara seimbang antara metode pembelajaran konvensional dengan pembelajaran berbasis game. Imersifitas yang baik dalam game akan mendorong anak untuk belajar sejarah lebih dalam lagi. Pendidikan dengan memanfaatkan imersifitas game diperlukan sebagai cara alternatif dalam proses belajar mengajar pada saat sekarang ini. Belajar melalui imersifitas game akan memberikan pengalaman belajar bagi pemain yang lebih dari membaca buku dan mendengarkan penjelasan dari guru. Pemain akan bermain game dan tidak merasa bahwa sebenarnya dia sedang belajar. Hal ini akan sesuai dengan tujuan belajar sambil bermain, yaitu membuat pintar anak didik dengan mengunakan pengalaman.

Dalam game sejarah seperti Samurai Warriors, pemain dijadikan menjadi salah satu pelaku sejarah. Dengan menjadi salah satu pelaku sejarah, mereka menjadi terlibat dalam peristiwa tersebut. Mereka akan mengalami pengalaman menjadi salah satu aktor sejarah. Pengalaman tersebut akan membekas dalam ingatan pemain. Pemain juga bisa melihat sejarah dari perspektif lain dengan memilih karakter lain. Perspektif ini akan semakin menguatkan pemahaman pemain terhadap sebuah sejarah. 


\section{DAFTAR PUSTAKA}

Balai Pelestarian Sejarah dan Nilai Tradisional Bandung. (2008). Workshop Penelitian dan Pengembangan Kebudayaan: Penulisan Karya Ilmiah dan Perekaman Data, materi workshop, Bandung, 12-14 Februari 2008.

Chin, Elliott \& Cohen, Mark (2004). Prima Official Game Guide: Samurai Warriors. Roseville: Prima Games.

Hamid, S. Hasan. (2010). Pendidikan Sejarah: Kemana dan Bagaimana?. Jurnal Pendidikan Sejarah-AGSI, 1, 6-10.

Jenkins, David. (2004). CESA Game Awards 2004 Announced. Diunduh dari Gamasutra website: http://www.gamasutra.com/view/news/95442/CESA_ Game_Awards_2004_Announced.php

Moody, M. Kyle J. (2005). Samurai Warriors: A Historical and Cultural Evaluation A Ninth and Tenth Grade English Language Arts Unit Prepared for the 2005 NCTA Southern California Fall Session. Diunduh dari UCLA International Institute website: http://www.international.ucla. edu/asia-archive/lessons/moody/moody.pdf

Negroponte, Nicholas. (1998). Being Digital: Menyiasati Hidup Dalam Cengkraman Sistem Komputer. Terj. Ahmad Baiquni. Bandung: Mizan.

Newman, James. (2004). Video Games. London: Routledge.

Schell, Jesse. (2008). The Art of Game Design: A Book of Lenses. Burlington: Morgan Kaufmann.

Slater, Stuart. (2002). Enhancing The Immersive Experience. School of Computing, Wolverhampton University.

Sweetser, Penelope \& Wyeth, Peta. (2005). GameFlow: a model for evaluating player enjoyment in games. Computers in Entertainment, 3(3), 1-24. 